HIV IN CHINA

\title{
Discriminatory attitudes towards people living with HIV/ AIDS and associated factors: a population based study in the Chinese general population
}

\author{
J T F Lau, H Y Tsui
}

Sex Transm Infect 2005;81:113-119. doi: 10.1136/sti.2004.011767

See end of article for authors' affiliations

.......................

Correspondence to: Professor Joseph T F Lau, Director, Centre for Epidemiology and Biostatistics, School of Public Health, Faculty of Medicine, The Chinese University of Hong Kong, $5 / F$, School of Public Health, Prince of Wales Hospital, Shatin, NT, Hong Kong; ilau@cuhk.edu.hk

Accepted for publication 27 July 2004
Objectives: To examine the level of discriminatory attitudes towards people living with HIV/AIDS (PLWHA) and factors in association with such attitudes.

Methods: A population based cross sectional telephone survey was conducted. A total of 808 Hong Kong Chinese aged 18-50 randomly selected from the general population participated in the study.

Results: Around $42 \%$ of the respondents exhibited discriminatory attitudes in at least five out of the 20 relevant items. For instance, about $42 \%$ would avoid making physical contact with PLWHA; $35 \%$ believed that all infected medical staff should be dismissed and about $47 \%$ would agree with enacting a law to prohibit PLWHA from visiting Hong Kong. A sizeable proportion of the respondents also hold negative perceptions about PLWHA (for example, $43.7 \%$ agreed that the majority of PLWHA are promiscuous, $20.7 \%$ thought that PLWHA are merely receiving the punishment they deserve, etc). Multiple regression analysis found that age, HIV related knowledge, the above mentioned negative perceptions about PLWHA, fear related to AIDS, and exposure to HIV related information were independent predictors of discriminatory attitudes towards PLWHA. About 30\% would give PLWHA the lowest priority in resource allocation among five groups of patients with chronic diseases.

Conclusions: The general public in Hong Kong has formed some negative perceptions of PLWHA. Discriminatory attitudes towards PLWHA are common and cover different aspects of their life. Intervention programmes are warranted and an integrated approach is required.
$\mathrm{D}$ iscrimination towards people living with HIV/AIDS (PLWHA) has been widely reported. ${ }^{1-4}$ Fear of discrimination was found to influence the use of HIV related prevention and care services. "Double stigmatisation" is another concern as PLWHA are often associated with some stigmatised social groups. ${ }^{6}$

The prevalence of HIV is low in Hong Kong, ${ }^{7}$ yet a substantial level of discriminatory attitudes towards PLWHA has been documented among adults, ${ }^{48}$ adolescents, ${ }^{9}$ social workers, ${ }^{10}$ health services providers, ${ }^{11}$ and people in the workplace. ${ }^{12}$ Around one third of the general public reported that they would avoid contacting an HIV infected friend ${ }^{4}$; about $40-50 \%$ of the local PLWHA thought they were being seriously discriminated against. ${ }^{13}$

It is reported that sociodemographic characteristics, HIV related knowledge, personal acquaintance with PLWHA, anti-homosexual attitudes, and perceived responsibility for the HIV infection, sympathy towards PLWHA, etc, were associated with discriminatory attitudes towards PLWHA. ${ }^{414-22}$ Few relevant studies have been conducted in the Chinese general populations. ${ }^{4}$ The present study investigates the prevalence of adults exhibiting various discriminatory attitudes towards PLWHA and associated factors in a Chinese population.

\section{METHODS}

\section{Study population and sampling}

A random telephone survey was conducted in November 2000. Random telephone numbers were selected from up to date telephone directories. Almost 100\% of the Hong Kong residents have telephones at home (Hong Kong Office of the Telecommunications Authority, personal communication, 28 January 2000). Of each sampled household, a Chinese member aged 18-50 and whose past birthday was closest to the day of the interview was invited to participate in the study. Interviews were conducted between $6 \mathrm{pm}$ to 10:30 pm to avoid over-representing unemployed individuals. Unanswered telephone calls were attempted at least two more times on separate evenings before being classified as invalid. A total of 808 respondents (383 males and 425 females) participated in the study. The response rate was about $53 \%$, which is comparable to other local telephone surveys. ${ }^{23} 24$ Ethics approval was obtained from the research ethics committee of the university.

\section{Measurements}

Sixty one items related to discriminatory attitudes towards PLWHA were first collected from a literature review. Ten local PLWHA were asked to rate the relevance of these candidate items. A pilot test was performed $(\mathrm{n}=40)$ and some items that had low discriminatory power were eliminated. A total of 20 items were hence selected (see table 2). Respondents indicated their level of agreement with these statements (on a five point scale, from 1 to 5). A composite score (Discriminatory Attitude Score (DAS)) was derived by obtaining the average score of the 20 items (ranged from 1 to 5) (Cronbach's $\alpha=0.84$ ). Higher scores meant more discrimination. Respondents were also asked (on a five point scale) whether they agreed or disagreed with another five statements related to negative perceptions about PLWHA. Other questions related to HIV and sociodemographic background were also asked (table 1).

Abbreviations: DAS, Discriminatory Attitude Score; PLWHA, people living with HIV/AIDS 
Table 1 HIV related knowledge/attitudes and perceptions about PLWHA by sociodemographic factors

\begin{tabular}{|c|c|c|c|c|c|c|c|c|c|}
\hline \multirow{3}{*}{$\begin{array}{l}\% \text { Agreeing or disagreeing } \\
\text { with the statements }\end{array}$} & \multicolumn{2}{|l|}{ Sex } & \multicolumn{2}{|l|}{ Age } & \multicolumn{2}{|c|}{ Education§ } & \multicolumn{2}{|c|}{ Marital status } & \multirow[b]{2}{*}{ All } \\
\hline & Male & Female & $18-35$ & $36-50$ & $\leqslant \mathrm{~F} .5$ & $>\mathrm{F} .5$ & Single & Others & \\
\hline & $\%$ & $\%$ & $\%$ & $\%$ & $\%$ & $\%$ & $\%$ & $\%$ & $\%$ \\
\hline $\begin{array}{l}\text { All* } \\
\text { HIV related knowledge }\end{array}$ & 47.4 & 52.6 & 54.8 & 45.2 & 68.3 & 31.7 & 40.0 & 60.0 & 100 \\
\hline $\begin{array}{l}\text { A person can contract HIV through } \\
\text { dinning together with PLWHA (disagree) } \ddagger\end{array}$ & 85.9 & 87.3 & 91.4 & $80.8+t$ & 85.8 & 88.3 & 91.0 & $83.9^{* *}$ & 86.6 \\
\hline $\begin{array}{l}\text { A person can contract HIV through } \\
\text { using a toilet seat that has just been used by } \\
\text { PLWHA (disagree) } \ddagger\end{array}$ & 72.3 & $60.9^{\star *}$ & 73.2 & $58.0+t$ & 62.8 & $73.8^{\star *}$ & 76.4 & $59.8+t$ & 66.3 \\
\hline $\begin{array}{l}\text { PLWHA can transmit HIV to others } \\
\text { through coughing (disagree) } \ddagger\end{array}$ & 68.9 & 64.7 & 72.3 & $59.6+t$ & 63.2 & $74.2^{\star *}$ & 73.3 & $62.3^{* *}$ & 66.7 \\
\hline $\begin{array}{l}\text { A person can contract HIV through } \\
\text { having mouth to mouth kissing with } \\
\text { PLWHA (disagree) } \ddagger\end{array}$ & 30.8 & 30.8 & 38.5 & $21.4 \dagger \dagger$ & 28.3 & 36.39 & 41.0 & $24.2 \mathrm{t \dagger}$ & 30.8 \\
\hline $\begin{array}{l}\text { A person cannot contract HIV through } \\
\text { just having brief bodily contact with } \\
\text { PLWHA (agree)t }\end{array}$ & 82.2 & 82.1 & 85.3 & 78.3ब & 80.8 & 85.2 & 85.1 & 80.3 & 82.2 \\
\hline $\begin{array}{l}\text { A person could appear healthy for a } \\
\text { long time after being infected with HIV } \\
\text { (agree)† }\end{array}$ & 66.3 & 60.2 & 63.5 & 62.4 & 60.1 & 69.5ब & 64.3 & 62.3 & 63.1 \\
\hline $\begin{array}{l}\text { HIV could be transmitted from a person } \\
\text { who looks healthy to others (agree) } † \\
\text { HIV related attitudes }\end{array}$ & 72.6 & 71.5 & 74.6 & 68.7 & 65.9 & $85.2 † \dagger$ & 76.4 & 68.99 & 72.0 \\
\hline $\begin{array}{l}\text { The current AIDS situation in Hong Kong is } \\
\text { serious (agree)t }\end{array}$ & 15.4 & 21.29 & 16.1 & 21.2 & 21.8 & $11.3+t$ & 14.6 & 21.19 & 18.4 \\
\hline Perceived that AIDS is horrible (agree)† & 66.6 & 66.8 & 62.1 & $72.3^{* *}$ & 66.8 & 66.8 & 61.5 & $70.4^{\star *}$ & 66.7 \\
\hline $\begin{array}{l}\text { Felt more fearful in contacting PLWHA, } \\
\text { compared to contacting other chronic } \\
\text { disease patients (eg, mentally ill) (agree) } † \\
\text { Negative perceptions about PLWHA }\end{array}$ & 24.8 & 28.2 & 20.0 & $34.9+t$ & 30.9 & $17.6+t$ & 18.6 & $31.9+t$ & 26.6 \\
\hline $\begin{array}{l}\text { The majority of PLWHA are promiscuous } \\
\text { (agree)t }\end{array}$ & 39.7 & 47.3ब & 34.5 & $54.9+\dagger$ & 51.4 & $27.0 \dagger \dagger$ & 32.3 & $50.9+t$ & 43.7 \\
\hline $\begin{array}{l}\text { PLWHA are merely receiving the } \\
\text { punishment they deserve (agree) } †\end{array}$ & 19.8 & 21.4 & 17.0 & $25.3^{* *}$ & 24.5 & $12.5 \mathrm{tt}$ & 15.2 & $24.4^{\star *}$ & 20.7 \\
\hline $\begin{array}{l}\text { PLWHA should feel ashamed of themselves } \\
\text { (agree) } \dagger\end{array}$ & 11.7 & 13.2 & 7.7 & $18.4 † \dagger$ & 14.9 & $7.4^{* *}$ & 8.4 & $15.1^{* *}$ & 12.5 \\
\hline PLWHA deserve sympathy (disagree) $\ddagger$ & 12.3 & 15.3 & 11.6 & 16.89 & 15.2 & 10.9 & 9.6 & $16.8^{\star *}$ & 13.9 \\
\hline $\begin{array}{l}\text { PLWHA would not make other colleagues } \\
\text { apprehensive (disagree) } \ddagger\end{array}$ & 60.6 & 54.1 & 55.3 & 59.6 & 56.3 & 59.4 & 60.6 & 55.1 & 57.2 \\
\hline
\end{tabular}

\section{Statistical analysis}

$\chi^{2}$ Tests were used and relevant odds ratios were calculated. Bonferroni adjustment was performed. To examine the associations between discriminatory attitudes and other studied variables, both univariate (Pearson and Spearman correlation coefficients) and multivariate analysis (stepwise multiple linear regression using univariately significant variables as input variables) were performed. A p value $<0.05$ was taken as statistically significant. SPSS for Windows 11.01 (SPSS Inc, Chicago, IL, USA) was used for all statistical analyses.

\section{RESULTS}

\section{Background characteristics}

The sociodemographic characteristics of the respondents are summarised in table 1. Around 3\% of the respondents had some PLWHA acquaintance and most of the respondents $(88.4 \%)$ had not received any HIV related information in the past 2 weeks.

\section{HIV related knowledge/attitudes and negative perceptions about PLWHA}

For all but one item ("kissing"), over $60 \%$ of the respondents gave a correct answer to questions on HIV related knowledge (table 1). About $18 \%$ perceived that the current AIDS situation in Hong Kong to be serious; nearly 67\% perceived that AIDS is horrible. About $26.6 \%$ felt more fearful in contacting PLWHA than contacting patients of other chronic diseases. Many respondents possessed negative perceptions towards PLWHA with regard to the five relevant questions asked. Sociodemographic differences were also noted (table 1).

\section{Level of discriminatory attitudes}

The results are summarised in table 2 . About $30 \%$ to $60 \%$ of the respondents would avoid making any physical contact with PLWHA (42\%), and believed that physicians should have the right in determining whether to serve PLWHA or not $(38.1 \%)$, that all PLWHA medical staff should be dismissed (35\%), that insurance companies should refuse PLWHA's insurance $(31.7 \%)$, that it is necessary to enact a law to criminalise the sexual activity of PLWHA (57.2\%), and that it is necessary to enact a law to prohibit PLWHA foreign visitors from visiting Hong Kong (47.3\%). Nearly 10\% would want their PLWHA neighbours to move away. About 6\% agreed that PLWHA should move out of their home and 3\% were unwilling to take care of HIV infected family members. Overall, $94.7 \%$ of the respondents showed some discriminatory attitudes in at least one of the 20 items $(42.3 \%$ for $\geqslant 5$ items).

\section{Factors associated with discriminatory attitudes}

Sex differences were observed only in two items (items 12 and 14; table 2). Younger respondents, those with post-Form 5 education level, and those who were single were less 
Table 2 Relations between discriminatory attitudes towards PLWHA and sociodemographic characteristics (univariate analysis)

\begin{tabular}{|c|c|c|c|c|c|c|c|c|c|}
\hline \multirow[b]{3}{*}{$\%$ Agreeing or disagreeing the statements: } & \multicolumn{2}{|l|}{ Sex } & \multicolumn{2}{|l|}{ Age } & \multicolumn{2}{|c|}{ Education level } & \multicolumn{2}{|c|}{ Marital status } & \multirow[b]{2}{*}{ All } \\
\hline & Male & Female & $18-35$ & $36-50$ & $\leqslant$ F.5 & $>$ F.5 & Single & Others & \\
\hline & $\%$ & $\%$ & $\%$ & $\%$ & $\%$ & $\%$ & $\%$ & $\%$ & $\%$ \\
\hline $\begin{array}{l}1 \text { You would be willing to make personal } \\
\text { contact with PLWHA (eg, having meal } \\
\text { together) (disagree) } \ddagger\end{array}$ & 18.3 & 23.8 & 13.4 & $30.5^{\star \star} \dagger$ & 23.4 & $16.0 \S$ & 12.1 & $26.9^{* *} \dagger$ & 21.2 \\
\hline $\begin{array}{l}2 \text { You would avoid having physical contact } \\
\text { with PLWHA (eg, not swimming/playing } \\
\text { basketball with them) (agree)* }\end{array}$ & 39.7 & 43.3 & 34.0 & $51.1^{* *} \dagger$ & 43.2 & 38.3 & 32.6 & $47.4^{* *} \dagger$ & 41.6 \\
\hline $\begin{array}{l}3 \text { You would avoid making contact with } \\
\text { PLWHA friends (agree)* }\end{array}$ & 21.7 & 25.4 & 16.8 & $31.9^{* *} \dagger$ & 27.2 & $15.6^{* *} \dagger$ & 14.6 & $29.4^{* *} \dagger$ & 23.6 \\
\hline $\begin{array}{l}4 \text { Employers should refuse to employ } \\
\text { PLWHA staff (agree)* }\end{array}$ & 13.1 & 14.6 & 9.3 & $19.5^{\star \star} \dagger$ & 16.2 & 9.0 ब & 7.5 & $18.2^{* *} \dagger$ & 13.9 \\
\hline $\begin{array}{l}5 \text { You would refuse to work with a } \\
\text { PLWHA (agree)* }\end{array}$ & 14.4 & 12.7 & 8.8 & $19.2^{* *} \dagger$ & 15.4 & $9.4 \S$ & 8.4 & $17.0^{* *} \dagger$ & 13.5 \\
\hline $\begin{array}{l}6 \text { PLWHA should be prohibited from } \\
\text { using public medical facilities (agree)* }\end{array}$ & 19.3 & 19.5 & 15.2 & $24.7 \oplus$ & 22.7 & $12.5^{\top}$ & 14.6 & $22.8 \uparrow$ & 19.4 \\
\hline $\begin{array}{l}7 \text { All PLWHA medical staff should be } \\
\text { dismissed (agree)* }\end{array}$ & 33.2 & 36.7 & 33.3 & 37.1 & 37.6 & $29.7 \S$ & 35.1 & 35.2 & 35.0 \\
\hline $\begin{array}{l}8 \text { Physicians should have the right in } \\
\text { determining whether to serve PLWHA } \\
\text { or not (agree)* }\end{array}$ & 37.3 & 38.8 & 36.5 & 39.8 & 40.3 & 33.2 & 36.6 & 38.9 & 38.1 \\
\hline $\begin{array}{l}9 \text { PLWHA should try to minimise their } \\
\text { attendance of public activities (eg, funfair, } \\
\text { concert) (agree) }\end{array}$ & 16.4 & 16.5 & 10.4 & $23.9^{* *} \dagger$ & 19.8 & $9.4^{* *} \dagger$ & 8.7 & $21.5^{* *} \dagger$ & 16.5 \\
\hline $\begin{array}{l}10 \text { PLWHA should move out of their home, } \\
\text { not living together with their family members } \\
\text { (agree)* }\end{array}$ & 4.7 & 7.3 & 2.7 & $10.2^{* *} \dagger$ & 7.6 & $2.7{ }^{\circ}$ & 2.2 & $8.7^{* *} \dagger$ & 6.1 \\
\hline $\begin{array}{l}11 \text { PLWHA should be prohibited from } \\
\text { looking after their children who are under } \\
18 \text { years of age (agree)* }\end{array}$ & 15.1 & 16.2 & 12.7 & $19.2 \S$ & 16.9 & 13.3 & 10.6 & 19.39 & 15.7 \\
\hline $\begin{array}{l}12 \text { You would want your PLWHA } \\
\text { neighbours to move away (agree)* }\end{array}$ & 12.5 & $7.5 \S$ & 6.1 & $14.6^{* *} \dagger$ & 11.4 & $6.6 \S$ & 5.6 & 12.8 & 9.9 \\
\hline $\begin{array}{l}13 \text { You would not feel uncomfortable } \\
\text { if you had PLWHA neighbours (disagree) } \ddagger\end{array}$ & 24.0 & 28.0 & 23.6 & 29.1 & 27.9 & 22.3 & 19.6 & $30.4^{\top}$ & 26.1 \\
\hline $\begin{array}{l}14 \text { You would object to PLWHA service } \\
\text { facilities in your neighbourhood (agree)* }\end{array}$ & 19.1 & $25.2 \S$ & 19.7 & $25.5 \S$ & 25.2 & $16.0^{\circ}$ & 16.8 & $25.99^{\circ}$ & 22.3 \\
\hline $\begin{array}{l}15 \text { All PLWHA school staff should be } \\
\text { dismissed (agree)* }\end{array}$ & 18.3 & 20.9 & 12.9 & $28.0^{* *} \dagger$ & 23.6 & $11.3^{* \star} \dagger$ & 11.8 & $25.1^{* *} \dagger$ & 19.7 \\
\hline $\begin{array}{l}16 \text { It is necessary to enact a law } \\
\text { prohibiting PLWHA foreign visitors } \\
\text { from visiting Hong Kong (agree) }\end{array}$ & 44.9 & 49.4 & 43.8 & $51.6 \S$ & 52.3 & $36.3^{* *} \dagger$ & 39.1 & $52.4^{* *} \dagger$ & 47.3 \\
\hline $\begin{array}{l}17 \text { It is necessary to enact a law making } \\
\text { PLWHA publicly disclose their HIV status } \\
\text { (agree)* }\end{array}$ & 16.4 & 21.2 & 15.9 & $22.8 \S$ & 19.8 & 17.2 & 15.5 & $21.1 \S$ & 18.9 \\
\hline $\begin{array}{l}18 \text { It is necessary to enact a law that sexual } \\
\text { activity of PLWHA should be criminalised } \\
\text { (regardless of whether the sex partner was } \\
\text { informed) (agree)* }\end{array}$ & 59.5 & 55.1 & 52.4 & $63.2^{\circ}$ & 59.2 & 52.7 & 51.6 & $60.7 \S$ & 57.2 \\
\hline $\begin{array}{l}19 \text { Insurance companies should refuse } \\
\text { PLWHA's insurance (agree) }\end{array}$ & 32.4 & 31.1 & 29.0 & 35.2 & 32.7 & 29.7 & 28.0 & 34.4 & 31.7 \\
\hline $\begin{array}{l}20 \text { If your family members unfortunately } \\
\text { contract HIV, you are willing to take care of } \\
\text { their daily living (disagree) } \ddagger\end{array}$ & 3.1 & 3.3 & 2.9 & 3.6 & 3.8 & 2.0 & 3.1 & 3.3 & 3.2 \\
\hline $\begin{array}{l}\text { Discriminatory attitudes in } \geqslant 5 \text { of the above } \\
\text { items }\end{array}$ & 40.2 & 44.2 & 34.5 & $51.9^{* *}$ & 46.6 & $32.8^{\star *}$ & 32.0 & $49.1^{\star *}$ & 42.3 \\
\hline
\end{tabular}

discriminatory than others (table 2). Many of the items remained statistically significant after Bonferroni adjustment was performed $(\mathrm{p}<0.001)$. Religion and housing type were not statistically significantly associated with any of the 20 above mentioned items (data not tabulated).

Adjusting for background factors listed in table 1, respondents with less understanding on HIV related knowledge, perceiving AIDS to be horrible, agreeing that the current AIDS situation in Hong Kong to be serious, and not having received HIV/AIDS related information in the past 2 weeks before the interview were more likely than others to exhibit discriminatory attitudes towards PLWHA (table 3). Similarly, the five items related to negative perceptions about PLWHA were all significantly associated with discriminatory responses (table 4).
Univariately, age groups (Pearson $r=0.29$; Spearman $r=$ 0.27), education level (Pearson $r=-0.22$; Spearman $r=-0.20$ ), marital status (Pearson $r=0.24$; Spearman $r=0.24$; this dichotomous variable was also significant when Student's $t$ test was used), whether received HIV/ AIDS related information in the past 2 weeks (Pearson $r=0.11$; Spearman $r=0.12$; this dichotomous variable was also significant when Student's $t$ test was used), number of correct HIV related knowledge items (Pearson $r=-0.37$; Spearman $r=-0.33)$, the three HIV related attitudes listed in table 1 (Pearson $r=0.12$ to 0.44 ; Spearman $r=0.09$ to 0.44 ), and all five items related to perception about PLWHA listed in table 1 (both Pearson and Spearman $r=0.15$ to 0.36 ) were all significantly associated with DAS. 
Table 3 Relations between discriminatory attitudes towards PLWHA and HIV related knowledge and attitudes

\begin{tabular}{|c|c|c|c|c|c|c|c|c|c|c|c|c|}
\hline \multirow{3}{*}{$\begin{array}{l}\% \text { Agreeing or disagree } \\
\text { with the statements: }\end{array}$} & \multicolumn{3}{|c|}{$\begin{array}{l}\text { No of correct HIV } \\
\text { knowledge itemst† }\end{array}$} & \multicolumn{3}{|c|}{$\begin{array}{l}\text { Perceived AIDS } \\
\text { as horrible }\end{array}$} & \multicolumn{3}{|c|}{$\begin{array}{l}\text { Perceived AIDS situation } \\
\text { in HK to be serious }\end{array}$} & \multicolumn{3}{|c|}{$\begin{array}{l}\text { Received HIV/AIDS } \\
\text { information } \ddagger \ddagger\end{array}$} \\
\hline & \multirow{2}{*}{$\begin{array}{l}0-4 \text { items } \\
\%\end{array}$} & \multirow{2}{*}{$\begin{array}{l}5-7 \text { items } \\
\%\end{array}$} & \multirow{2}{*}{$\begin{array}{l}\text { Adj } \\
\text { OR }\end{array}$} & \multirow{2}{*}{$\begin{array}{l}\text { Agree } \\
\%\end{array}$} & \multirow{2}{*}{$\begin{array}{l}\text { Else } \\
\%\end{array}$} & \multirow{2}{*}{$\begin{array}{l}\text { Adi } \\
\text { OR }\end{array}$} & \multirow{2}{*}{$\begin{array}{l}\text { Agree } \\
\end{array}$} & \multirow{2}{*}{$\begin{array}{l}\text { Else } \\
\%\end{array}$} & \multirow{2}{*}{$\frac{\text { Adj }}{\text { OR }}$} & \multirow{2}{*}{$\begin{array}{l}\text { No } \\
\%\end{array}$} & \multirow{2}{*}{$\begin{array}{l}\text { Yes } \\
\end{array}$} & \multirow{2}{*}{$\begin{array}{l}\text { Adi } \\
\text { OR }\end{array}$} \\
\hline & & & & & & & & & & & & \\
\hline $\begin{array}{l}1 \text { You would be willing to } \\
\text { make personal contact with } \\
\text { PLWHA (eg, having meal } \\
\text { together) (disagree)** }\end{array}$ & 31.9 & 13.3 & $0.38 \S \dagger$ & 26.2 & 11.2 & $2.65 \S \dagger$ & 27.5 & 19.7 & 1.40 & 22.3 & 12.8 & $1.96^{*}$ \\
\hline $\begin{array}{l}2 \text { You would avoid having } \\
\text { physical contact with PLWHA } \\
\text { (eg, not swimming/playing } \\
\text { basketball with them) (agree) }\end{array}$ & 52.3 & 33.7 & $0.50 \S \dagger$ & 45.8 & 33.1 & $1.62 \ddagger$ & 50.3 & 39.6 & $1.49^{\star}$ & 42.7 & 33.0 & 1.55 \\
\hline $\begin{array}{l}3 \text { You would avoid making } \\
\text { contact with PLWHA friends } \\
\text { (agree) }\end{array}$ & 33.3 & 16.5 & $0.46 \S \dagger$ & 28.6 & 13.8 & $2.42 \S \dagger$ & 28.9 & 22.5 & 1.23 & 24.8 & 14.9 & $1.93^{*}$ \\
\hline $\begin{array}{l}4 \text { Employers should refuse to } \\
\text { employ PLWHA staff (agree) }\end{array}$ & 19.9 & 9.4 & $0.50 \ddagger$ & 17.8 & 5.9 & $3.15 \S \dagger$ & 19.5 & 12.6 & 1.46 & 14.8 & 6.4 & $3.20^{*}$ \\
\hline $\begin{array}{l}5 \text { You would refuse to work } \\
\text { with a PLWHA (agree) }\end{array}$ & 20.5 & 8.4 & $0.39 \S \dagger$ & 17.4 & 5.6 & $3.28 \S \dagger$ & 18.1 & 12.4 & 1.44 & 14.6 & 5.3 & $3.23^{*}$ \\
\hline $\begin{array}{l}6 \text { PLWHA should be } \\
\text { prohibited from using public } \\
\text { medical facilities (agree) }\end{array}$ & 24.0 & 16.1 & 0.74 & 21.0 & 16.4 & 1.31 & 27.5 & 17.6 & $1.63^{*}$ & 20.2 & 13.8 & 1.58 \\
\hline $\begin{array}{l}7 \text { All PLWHA medical staff } \\
\text { should be dismissed (agree) }\end{array}$ & 37.7 & 33.0 & 0.85 & 41.6 & 21.9 & $2.55 \S \dagger$ & 40.9 & 33.7 & 1.25 & 36.0 & 27.7 & 1.51 \\
\hline $\begin{array}{l}8 \text { Physicians should have the } \\
\text { right in determining whether to } \\
\text { serve PLWHA or not (agree) }\end{array}$ & 36.8 & 39.1 & 1.19 & 37.7 & 39.0 & 0.92 & 37.6 & 38.2 & 0.95 & 38.8 & 33.0 & 1.25 \\
\hline $\begin{array}{l}9 \text { PLWHA should try to minimise } \\
\text { their attendance of public } \\
\text { activities (eg, funfair, concert) } \\
\text { (agree) }\end{array}$ & 26.3 & 9.2 & $0.34 \S \dagger$ & 20.2 & 8.9 & $2.34 \ddagger$ & 26.8 & 14.1 & $1.98 \ddagger$ & 17.2 & 10.6 & 1.85 \\
\hline $\begin{array}{l}10 \text { PLWHA should move out } \\
\text { of their home, not living } \\
\text { together with their family } \\
\text { members (agree) }\end{array}$ & 11.1 & 2.4 & $0.23 \S \dagger$ & 8.0 & 2.2 & $3.29 \ddagger$ & 11.4 & 4.9 & 2.10* & 6.6 & 2.1 & 3.21 \\
\hline $\begin{array}{l}11 \text { PLWHA should be } \\
\text { prohibited from looking after } \\
\text { their children who are under } \\
18 \text { years of age (agree) }\end{array}$ & 19.3 & 13.1 & 0.70 & 18.7 & 9.7 & $2.04 \ddagger$ & 25.5 & 13.5 & $1.97 \ddagger$ & 16.5 & 9.6 & 1.85 \\
\hline $\begin{array}{l}12 \text { You would want your } \\
\text { PLWHA neighbours to move } \\
\text { away (agree) }\end{array}$ & 15.2 & 6.0 & $0.36 \S \dagger$ & 13.9 & 1.9 & $7.64 \S \dagger$ & 14.8 & 8.8 & $1.82^{\star}$ & 10.4 & 6.4 & 1.89 \\
\hline $\begin{array}{l}13 \text { You would not feel } \\
\text { uncomfortable if you } \\
\text { had PLWHA neighbours } \\
\text { (disagree) }^{* *}\end{array}$ & 31.6 & 22.1 & $0.65^{\star}$ & 30.1 & 18.2 & $1.77 \ddagger$ & 36.9 & 23.7 & $1.84 \ddagger$ & 26.2 & 25.5 & 1.07 \\
\hline $\begin{array}{l}14 \text { You would object to } \\
\text { PLWHA service facilities in }\end{array}$ & 31.9 & 15.2 & $0.42 \S \dagger$ & 28.2 & 10.4 & $3.25 \S \dagger$ & 28.9 & 20.8 & 1.41 & 22.8 & 18.1 & 1.29 \\
\hline $\begin{array}{l}\text { your neighbourhood (agree) } \\
15 \text { All PLWHA school staff } \\
\text { should be dismissed (agree) }\end{array}$ & 26.6 & 14.6 & $0.58 \ddagger$ & 24.1 & 10.8 & $2.47 \S \dagger$ & 27.5 & 17.9 & 1.53 & 21.3 & 7.4 & $3.41 \ddagger$ \\
\hline $\begin{array}{l}16 \text { It is necessary to enact a } \\
\text { law prohibiting PLWHA } \\
\text { foreign visitors from visiting } \\
\text { Hong Kong (agree) }\end{array}$ & 54.4 & 42.1 & $0.71^{*}$ & 53.4 & 34.9 & $2.17 \S \dagger$ & 57.0 & 45.1 & $1.50^{*}$ & 48.7 & 36.2 & $1.64^{*}$ \\
\hline $\begin{array}{l}17 \text { It is necessary to enact a } \\
\text { law making PLWHA publicly } \\
\text { disclose their HIV status } \\
\text { (agree) }\end{array}$ & 22.2 & 16.5 & 0.76 & 20.0 & 16.7 & 1.16 & 27.5 & 17.0 & $1.74^{\star}$ & 18.8 & 20.2 & 0.90 \\
\hline $\begin{array}{l}18 \text { It is necessary to enact a } \\
\text { law that sexual activity of } \\
\text { PLWHA should be criminalised } \\
\text { (regardless of whether the sex } \\
\text { partner was informed) (agree) }\end{array}$ & 62.9 & 53.0 & $0.73^{*}$ & 60.9 & 49.8 & $1.54 \ddagger$ & 56.4 & 57.4 & 0.93 & 57.4 & 55.3 & 1.09 \\
\hline $\begin{array}{l}19 \text { Insurance companies } \\
\text { should refuse PLWHA's } \\
\text { insurance (agree) }\end{array}$ & 34.8 & 29.4 & 0.80 & 33.4 & 28.3 & 1.21 & 31.5 & 31.7 & 0.94 & 32.2 & 27.7 & 1.26 \\
\hline $\begin{array}{l}20 \text { If your family members } \\
\text { unfortunately contract HIV, } \\
\text { you are willing to take care of } \\
\text { their daily living (disagree) }\end{array}$ & 4.1 & 2.6 & 0.67 & 3.0 & 3.7 & 0.78 & 4.7 & 2.9 & 1.50 & 3.2 & 3.2 & 1.03 \\
\hline $\begin{array}{l}\text { Discriminatory attitudes in } \\
\geqslant 5 \text { of the above items }\end{array}$ & 55.0 & 33.0 & $0.46 \S$ & 49.5 & 27.9 & $2.44 \S$ & 50.3 & 40.5 & 1.35 & 43.8 & 30.9 & $1.75^{*}$ \\
\hline
\end{tabular}

Adj OR, odds ratios adjusted for background factors including sex, age, education level, marital status, religion, and housing type. * $p<0.05$; $\ddagger p<0.01$; $\$ p$ $<0.001$. TSignificant at $p<0.0025$ level after Bonferroni adjustment.

- Agreed or strongly agreed with the statement. * Disagreed or strongly disagreed with the statement. $+\dagger$ Number of correct answers to the seven HIV related knowledge items listed in table 2. \#‡Had received HIV/AIDS related information in the last 2 weeks before the interview. 


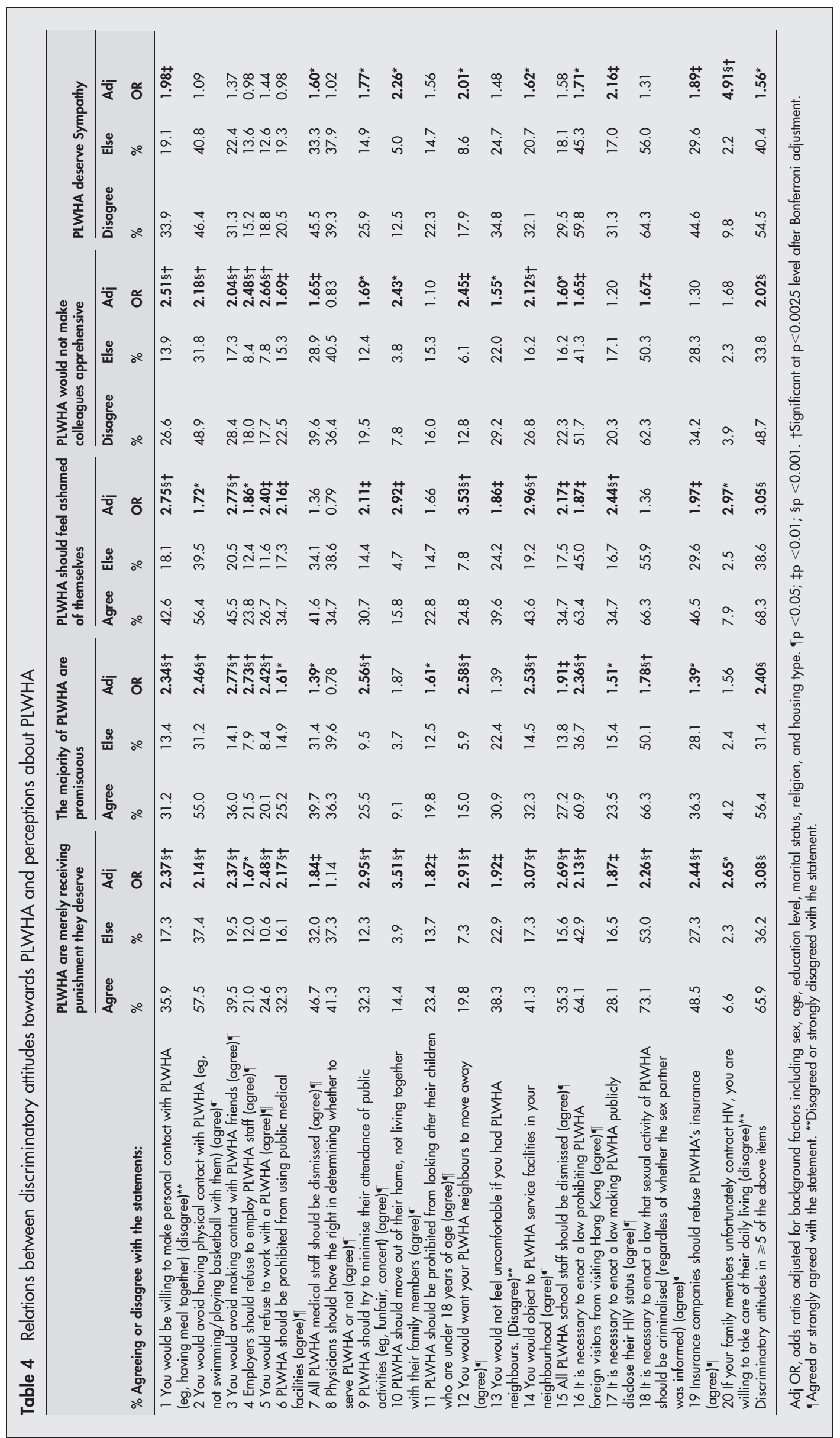


Results of the stepwise multiple linear regression analysis (adjusted $\left.\mathrm{R}^{2}=0.42\right)$ showed that age $(\beta=0.11, \mathrm{p}<0.001)$, lack of exposure to HIV related information in the past 2 weeks $(\beta=0.07, p<0.05)$, number of correct HIV knowledge items $(\beta=-0.18, p<0.001)$, perception that AIDS is horrible $(\beta=0.15, p<0.001)$, felt more fearful in contacting PLWHA than other patients with chronic diseases $(\beta=0.26$, $\mathrm{p}<0.001)$, perceiving that the majority of PLWHA are promiscuous $(\beta=0.1, p<0.01)$, perceiving that PLWHA are merely receiving the punishment they deserve $(\beta=0.13$, $\mathrm{p}<0.001$ ), perceiving that PLHWA should feel ashamed of themselves $(\beta=0.1, p<0.01)$, perceiving that PLWHA as not deserve sympathy $(\beta=0.1, p<0.05)$, and perceiving that PLWHA would make other colleagues apprehensive $(\beta=0.08, p<0.01)$ were all independently associated with DAS (data not tabulated).

\section{Resource allocation}

About $31 \%$ of the respondents would give the lowest priority in resource allocation to PLWHA, compared with four other chronic diseases (mental illness, cancer, heart disease, and kidney disease). Marital status, but not other variables listed in table 1 , was of statistical significance.

\section{DISCUSSION}

The study demonstrated that discriminatory attitudes towards PLWHA have been common in Hong Kong. The results are consistent with those obtained from other studies. ${ }^{4}{ }^{13}$ PLWHA in Hong Kong have been strongly stigmatised. For instance, a noticeable proportion of the general population perceived PLWHA to be promiscuous and would make their colleagues apprehensive; many respondents thought that PLWHA were merely receiving punishment that they deserve or even thought that PLWHA should be ashamed of themselves. Consistent with international literature, the above mentioned stigma and negative perceptions were significantly associated with discriminatory attitudes. ${ }^{4021}$ Moral values are likely to be associated with their disease status, possibly because of their association with various vulnerable groups that have been marginalised in the society. Education programmes should thus portray PLWHA as useful members of the community, instead of emphasising their memberships in vulnerable groups.

The literature has shown that programmes using PLWHA as educators tended to be effective. ${ }^{25}$ However, only two late PLWHA in Hong Kong disclosed their HIV status in public and nearly $80 \%$ of the PLWHA worried that their HIV status would be made known to others. ${ }^{13}$ A vicious cycle of nondisclosure, misunderstanding, and discrimination may thus be in operation.

Consistent with other local and international studies, ${ }^{4} 1519$ the level of HIV related knowledge is negatively associated with discriminatory attitudes, yet, lack of knowledge is only one of the significant variables in the multivariate model. About two thirds of respondents thought that AIDS is horrible and about a quarter expressed that they were more fearful of being in contact with PLWHA than patients with other chronic disease. These factors were independent predictors of discriminatory attitudes. Fear may thus be another important source of discriminatory attitudes. Paradoxically, worrying about contracting the disease and perceiving serious disease consequences may have favourable impacts on prevention. ${ }^{26}{ }^{27} \mathrm{~A}$ balance between prevention and discrimination considerations is required.

Like other studies, ${ }^{419}$ the univariate analyses showed that those who were married or with lower education attainment tended to be more discriminatory; this was not true in the multivariate analysis. An explanation is that those who were less educated or married may tend to be less knowledgeable, more fearful towards AIDS, and more likely to have negative perceptions about PLWHA, etc.

It is encouraging to see that those who received some HIV related information in the past 2 weeks tended to exhibit less discriminatory attitudes. Another local study showed that discriminatory attitudes among adolescents could largely be reduced by a simple intervention programme. ${ }^{28}$ Few intervention programmes have been targeting adults in Hong Kong and in mainland China. These programmes are most warranted and should be supported by other programmes attempting to reduce stigmatisation of vulnerable social groups.

Until now, highly active antiretroviral therapy (HAART) and a number of other supportive services (including counselling services) are offered free to all PLWHA attending public clinics. Increased years of life are expected and PLWHA are thus patients with chronic disease. The interesting fact that about $31 \%$ of the respondents would give resource allocation to PLWHA the lowest priority, compared to four other types of chronic disease is also worth some attention. It is speculated that HIV/AIDS is often not seen as a typical chronic disease in Hong Kong. This compartmentalisation does not help to convince the public that the rights of the PLWHA are not different from those patients with other chronic diseases.

The study has several limitations. Firstly, self reported data may be subjected to presentation bias, though the study is anonymous and the existence of bias should underestimate the degree of discriminatory attitudes. Secondly, discriminatory attitudes, instead of behaviours, were studied. Discriminatory attitudes may be related to behaviours, and as such would affect the feelings and behaviours of the PLWHA. As few of the general population had an experience of having direct interaction with PLWHA, a study of discrimination behaviours is difficult. Thirdly, the response rate is moderate (about 53\%), though it is comparable to that of other local telephone surveys ${ }^{23}{ }^{24}$; besides, no data were available from the non-responders. The composition of the sample, however, is roughly comparable with that of the census population. Fourthly, the cross sectional nature of the study would not allow for inference of causality.

\section{Key messages}

- Using items generated from literature review and interviewing people living with HIV/AIDS (PLWHA), this study shows that discriminatory attitudes towards PLWHA are common in Hong Kong. These are strongly associated with other negative perceptions, such as that PLWHA are promiscuous. Moral judgment therefore has a strong role in discrimination towards PLWHA

- Promotion of HIV related knowledge is important but probably insufficient to reduce discrimination. Removal of irrational fear is also important. The need for balancing prevention and reduction of discrimination is required in this regard

- Intervention programmes are warranted. They should not emphasise PLWHA's membership in vulnerable groups. Instead, they should be portrayed as patients with chronic disease who may still contribute to society. Such programmes should also be supported by those attempting to reduce stigma of other marginalised social groups. 
Discriminatory attitudes are common in Hong Kong. Hong Kong is an open and well informed society; so discriminatory attitudes may be even more common in mainland China, where people may be less informed. An integrated and multidirectional approach of providing relevant knowledge, removing fear, and negative perceptions is warranted.

\section{ACKNOWLEDGEMENTS}

The study was supported by the Hong Kong Council for the AIDS Trust Fund. The authors would also like to thank Ms MW Chan for her assistance in data collection.

\section{CONTRIBUTORS}

$\mathrm{JL}$ is the principal investigator of the study, he participated in the conception, design, initiation, and implementation of the study, interpretation of data, and drafting of the paper, he is the lead writer; HYT participated in the conception and design of the study, conducted the statistical analyses for the study and interpretation of data, she also contributed to drafting the paper.

\section{Authors' affiliations}

J T F Lau, H Y Tsui, Centre for Epidemiology and Biostatistics School of Public Health, Faculty of Medicine The Chinese University of Hong Kong The study was supported by the Hong Kong Council for the AIDS Trust Fund.

\section{REFERENCES}

1 Blendon RJ, Donelan K. Discrimination against people with AIDS: the public's survey on perspective. N Engl J Med 1988;319:1022-6.

2 Danziger R. Discrimination against people with HIV and AIDS in Poland. BMJ 1994;308:1145-7.

3 King MB. Prejudice and AIDS: the views and experiences of people with HIV infection. AIDS Care 1989;1:137-43.

4 Lau JTF, Tsui HY. Surveillance of discriminatory attitudes toward people living with HIV/AIDS among the general public in Hong Kong from 1994 to 2000. Disabil Rehabil 2003;25:1354-60.

5 Chesney MA, Smith AW. Critical delays in HIV testing and care: the potential role of stigma. American Behavioral Scientist 1999;42:1162-74.

6 Herek GM, Glunt EK. An epidemic of stigma: public reactions to AIDS. Am Psychol 1988;43:886-891.

7 Advisory Council on AIDS. HIV/AIDS statistics in Hong Kong (updated 31 December 2003). ACA Newsfile 2004;11:11. Hong Kong: Advisory Council on AIDS.

8 Hong Kong AIDS Foundations. The knowledge, attitude, behaviour and practice survey on AIDS in Hong Kong 1992. Hong Kong AIDS Foundations, 1996.
9 Davis C, Noel MB, Chan FSF, et al. Knowledge, attitudes and behaviors related to HIV and AIDS among Chinese adolescents in Hong Kong. J Adolesc 1998;21:657-65.

10 Lau JTF, Ma P. Survey on knowledge/attitude among social welfare personnel. Report submitted to the Hong Kong Council of Social Service, 1995.

11 Lau JTF, Lee SS. Attitudes and training of health care workers on AIDS in Hong Kong. Paper presented at the Xlth International Conference on AIDS Vancouver, Canada, 7-12 July 1996.

12 Lau JTF, Wong WS. AIDS-related discrimination in the workplace: The results of two evaluative surveys carried out during a 3-year period in Hong Kong. AIDS Care $2001 ; 13: 433-40$.

13 Lau JTF, Tsui HY, Li CK, et al. Needs assessment and social environment of people living with HIV/AIDS in Hong Kong. AIDS Care 2003;15:699-706.

14 Bermingham S, Kippax S. HIV-related discrimination: a survey of New South Wales general practitioners. Aust N Z J Public Health 1998;22:92-7.

15 Chliaoutakis J, Trakas DJ. Stigmatization, discrimination and fear of AIDS in Greece: Implications for health policy. Ethn Health 1996;1:359-71.

16 Dekker P, Mootz M. AIDS as threat, AIDS as stigma: correlates of AIDS beliefs among Dutch general public. Psychology and Health 1992;6:347-65.

17 Gerbert B, Sumser J, Maguire BT. The impact of who you know and where you live on opinions about AIDS and health care. Soc Sci Med 1991;32:677-81.

18 Noble J, Kippax S, Crawford J. Some demographic correlates of HIV/AIDS-related discrimination. Australian Journal of Social Issues 1995;30:310-24.

19 Price V, Hsu ML. Public opinion about AIDS policies: the role of misinformation and attitudes toward homosexuals. Public Opinion Quarterly 1992;56:29-52.

20 Leone C, Wingate C. A functional approach to understanding attitudes toward AIDS victims. J Soc Psychol 1991;131:761-8.

21 Peters L, den Boer DJ, Kok G, et al. Public reactions towards people with AIDS: an attributional analysis. Patient Education and Counseling 1994;24:323-35

22 Dijker AJ, Kok G, Koomen W. Emotional reactions to people with AIDS. Journal of Applied Social Psychology 1996;26:731-48.

23 Chou KL, Mak KY, Chung PK, et al. Attitudes towards mental patients in Hong Kong. Int J Soc Psychiatry 1996;42:213-19.

24 Wong IL, So EM. Prevalence estimates of problem and pathological gambling in Hong Kong. Am J Psychiatry 2003;160:1353-4.

25 Dennehy EB, Edwards CA, Keller RL. AIDS education intervention utilizing a person with AIDS: examination and clarification. AIDS Educ Prev 1995:7:124-33.

26 Rosenstock IM, Strecher VJ, Becker MH. The health belief model and HIV risk behavior change. In: DiClemente RJ, Peterson JL, eds. Preventing AIDS: theories and methods of behavioral interventions. New York: Plenum Press, 1994:5-24.

27 Falck RS, Siegal HA, Wang J, et al. Usefulness of the health belief model in predicting HIV needle risk practices among injection drug users. AIDS Educ Prev 1995;7:523-33.

28 Lau JTF, Tsui HY, Chan K. Reducing discriminatory attitudes toward PLWHA in Hong Kong - an intervention study using a knowledge based, PLWHA participation and cognitive approach. AIDS Care 2005; 17:85-101. 